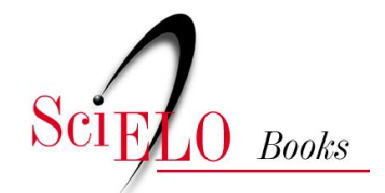

\title{
Utopias por um mundo melhor
}

\author{
Adalmir Leonidio
}

\section{SciELO Books / SciELO Livros / SciELO Libros}

LEONIDIO, A. Utopias por um mundo melhor. In: SOUSA, C. M., org.Um convite à utopia [online]. Campina Grande: EDUEPB, 2016. Um convite à utopia collection, vol. 1, pp. 135-167. ISBN: 97885-7879-488-0. Available from: doi: 10.7476/9788578794880.0004. Also available in ePUB from: http://books.scielo.org/id/kcdz2/epub/sousa-9788578794880.epub.

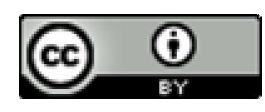

All the contents of this work, except where otherwise noted, is licensed under a Creative Commons Attribution $\underline{4.0 \text { International license. }}$

Todo o conteúdo deste trabalho, exceto quando houver ressalva, é publicado sob a licença Creative Commons Atribição 4.0.

Todo el contenido de esta obra, excepto donde se indique lo contrario, está bajo licencia de la licencia Creative Commons Reconocimento 4.0. 


\title{
UTOPIAS POR UM MUNDO MELHOR
}

\author{
Adalmir Leonidio ${ }^{1}$
}

\section{Introdução}

O termo utopia é antigo. Ele foi literalmente inventado pelo inglês Thomas More, em seu livro Utopia, no século XVI. Tanto a sua origem quanto a sua utilização ao longo dos séculos sempre foram alvo de muita confusão. Mas foi seguramente com Marx que ele adquiriu seu sentido mais difundido: o de "sonho", "fantasia", "evasão da realidade". Os "utópicos" tirariam de suas cabeças um sistema novo, mais perfeito, de ordem social, para tentar implantá-lo na sociedade ${ }^{3}$. Esta representação da utopia perdurou até o início do século XX. Nos anos vinte, Martin Buber caracterizou a "imagem utópica" como "um quadro do que deve ser", um estado ideal, portanto, mas sem a acepção negativa empregada por Marx e Engels. A utopia anseia pelo que é justo e experimenta, como revelação ou idéia, aquilo que não pode se realizar no indivíduo,

1 Doutor em Ciências Sociais e professor no Curso de História da Universidade Federal Rural do Rio de Janeiro.

2 MARX, Karl. Manifesto do Partido Comunista. In: MARX, K. \& ENGELS, F. Obras escolhidas. São Paulo: Alfa-Omega, s.d., p. 38-43.

3 ENGELS, F. Do socialismo utópico ao socialismo científico. In: MARX, K. \& ENGELS, F. Obras escolhidas. São Paulo: Alfa-Omega, s.d., p. 307. 
mas somente na comunidade humana. A visão daquilo que deve ser não pode no entanto ser separada da atitude crítica em face da atual maneira de ser do mundo ${ }^{4}$.

Partindo de Martin Buber, uma relativização interessante da idéia de "utopia" aparece com Karl Mannheim, em 1929. Segundo o pensador alemão, um "estado de espírito" é utópico quando, simultaneamente, transcende a realidade e assume uma conduta que tende a se opor, seja parcial ou totalmente, à ordem de coisas que prevalece no momento. Neste sentido ele é oposto ao "estado de espírito" ideológico, que, congruente ou incongruente com a realidade, tende a permanecer no nível da realização e da manutenção do status quo ${ }^{5}$.

Mais recentemente, Michel Löwy buscou mostrar que tanto para Marx e Engels, quanto para Mannheim, a utopia era concebida como uma forma de falsa consciência, isto é, uma representação que transcende a realidade. Segundo o autor, ideologia e utopia seriam, ambas, uma visão social de mundo, isto é, um estilo de pensamento ou ponto de vista socialmente condicionado. Uma visão social de mundo será utópica quando circunscrever um conjunto articulado e estruturado de valores, representações, idéias e orientações cognitivas que se oponha à ordem social vigente, propondo a realização, no presente ou no futuro, de uma nova sociedade, ou de reformas que alterem significativamente a sociedade em curso ${ }^{6}$.

Esta definição de Löwy para o conteúdo da utopia encerra, no entanto, alguns problemas. Antes de mais nada, vincular a utopia a uma forma radical de encarar a situação presente, exclui dela

\footnotetext{
4 BUBER, Martin. O socialismo utópico. São Paulo: Perspectiva, 1971.

5 MANNHEIM, Karl. Ideologia e utopia. Rio de Janeiro: Guanabara, 1986, p. 216.

6 LÖWY, Michel. As aventuras de Karl Marx contra o Barão de Münchhausen. São Paulo: Busca Vida,1987.
} 
grande parte da literatura que se convencionou chamar utópica, como More, um erasmista estrênuo, que capitulou frente a propostas mais radicais de reforma, como a de Thomas Müntzer. Por outro lado, segundo esta acepção, todo socialismo seria utópico, no sentido de que é uma visão de mundo que se opõe à sociedade capitalista. O que não é verdade, já que Saint-Simon, por exemplo, não se opôs ao capitalismo industrial de sua época, embora tenha idealizado uma sociedade mais igualitária.

Mas há ainda uma outra questão que foi muito pouco trabalhada pela bibliografia que trata do tema. Isto é, há uma variedade muito grande de utopias - utopias sociais, utopias políticas, utopias religiosas, utopias cientistas, entre outras -, de modo que dificilmente se poderia falar em utopia no singular, e de forma definitiva. Apesar disso, apostamos na hipótese da existência de elementos comuns aos diversos tipos de utopia, ainda que estes elementos se apresentem de forma um tanto diversa nos diferentes contextos históricos. O que este artigo pretende é, admitindo a utopia como um dado conteúdo, perceber os seus elementos constitutivos ao longo da história, suas continuidades e descontinuidades. O seu limite temporal será o período imediatamente posterior à Revolução Francesa, deixando de lado, portanto, toda forma de utopia que se desenvolve a partir do início do século XIX.

\section{A utopia através dos tempos: de Platão a Babeuf}

O Renascimento é o tempo que vê florescer a utopia. Mas se ela pôde então florescer, é porque já era uma planta com sólidas raízes. Por outro lado, sabe-se que esta época é marcada por uma volta à Antiguidade. Já se disse que o Renascimento, como fase de transição para a ciência moderna, colaborou grandemente para solapar as bases do aristotelismo. Foi uma aliança de Platão 
com Demócrito - ou Epicuro - que desmoronou o império de Aristóteles. Portanto, esta volta à Antiguidade é, também, uma revolta contra a Antiguidade e a tradição.

O objetivo de Platão é ensinar a virtude aos cidadãos, isto é, pretende construir uma república feliz através de uma reforma dos indivíduos. Partindo da dialética socrática ele vai tentar definir então o que é a virtude, até elevá-la a um modelo de conduta moral. E aqui já aparece um dos problemas centrais da utopia. Quase no final de seu livro pergunta-se Platão: "É possível executar uma coisa tal como se descreve? Ou está na natureza das coisas que a execução tenha menos influência sobre a verdade que o discurso?"' . Ele acabará por concluir pela segunda hipótese. Isto é, conhecer o Bem é já praticá-lo, uma vez que ninguém o conhece sem o desejar.

Mas por trás deste seu projeto de reforma dos indivíduos também aparece uma outra questão central para os utópicos, e que parece estar contida numa enigmática afirmação de Demócrito (460 - 370 a.C.): "Todos os seres vivos associam-se com seres vivos

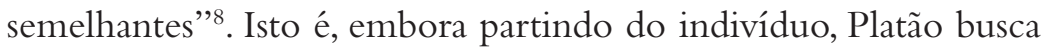
a unidade social.

A Justiça parece ser a principal virtude e o supremo bem de uma república feliz. Para Platão a natureza fez os indivíduos com diferentes aptidões, isto é, aptos para esta ou aquela função. As coisas são feitas em maior número, melhor e mais facilmente, quando cada um, segundo suas aptidões, se entrega a um único trabalho. A Justiça consiste, portanto, em "restituir a cada um o que lhe é próprio". Para o indivíduo, ser vir tuoso é exercer a função que

\footnotetext{
7 PLATÃO. A República. Lisboa: Europa-América, 1998, p. 204.

8 Cf. BORNHEIM, Gerd A. (org.). Os filósofos pré-socráticos. São Paulo: Cultrix, 1993.
} 
lhe cabe na sociedade. A hierarquização das funções sociais é, pois, a condição da harmonia e da concórdia na República platônica ${ }^{9}$.

O ideal para uma república, o seu maior bem é que ela seja una. Para tanto é preciso, em primeiro lugar, que cada indivíduo cumpra a sua função social. Secundariamente, que ela forme uma "comunidade de prazer e de dor". Toda a cidade deve compartilhar a alegria e a tristeza de cada indivíduo, e cada indivíduo não deve ver no outro senão um irmão ou uma irmã. Em seguida, devese suprimir "os dois temíveis inimigos da unidade", o interesse individual e o espírito de família. Suprimir-se-á o primeiro pela comunidade dos bens, o segundo pela comunidade das mulheres e dos filhos. Por fim, é preciso evitar os grandes estados, à maneira do império persa ${ }^{10}$.

Este último ideal de unidade, ancorado no pacifismo, espelha o seu desejo de alcançar a nova república através da simples persuasão, isto é, da não-violência. Como nas utopias que se desenvolverão a partir daqui, Platão deseja ver os reis aconselhados pelos filósofos, os portadores da utopia. $\mathrm{Na}$ alegoria da caverna vê- se claramente que é somente através do saber que se pode tornar a cidade-modelo uma realidade e não um sonho vão, como nas cidades de seu tempo, onde as pessoas se batem por sombras. $\mathrm{O}$ sonho, a ilusão é, portanto, aquilo que existe enquanto ignorância, e não aquilo que se projeta enquanto modelo ideal ${ }^{11}$.

Em Platão, o pensador é acompanhado por um incomparável artista, que a Musa dotou de todos os dons, entusiasmo do belo, imaginação rica, capacidade de sair de si próprio e de criar tipos de toda espécie, fantasia alada. Em dois outros diálogos, Timeu e

\footnotetext{
9 PLATÃO, A República, p. 31-60.

10 PLATÃO, A República, p. 190-193.

11 PLATÃO, A República, p. 205.
} 
Critias, Platão refere-se a uma viagem de Sólon ao Egito, onde este soube que os sacerdotes egípcios de Sais possuíam registros de "uma ilha continental além das Colunas de Hércules (antigo nome de Gibraltar) chamada Atlântida", o centro de um grande e maravilhoso império, que teria desaparecido após "uma grande inundação" ${ }^{2}$. Platão descreve este lugar como sendo o Jardim das Hespéredes, uma das versões gregas do paraíso terrestre ${ }^{13}$.

Mas outra característica interessante na descrição platônica, que depois será quase que uma obsessão entre os utópicos, é o gosto por contar, enumerar, planejar, ordenar. Nesta república ideal havia pontes ligando os principais pontos da cidade que se viam separados por rios e mares. O palácio real ficava no centro, e havia ligações de todos os lugares até ele. Ao redor ficavam as habitações. Os homens e bens circulavam graças a uma complexa rede de canais e estradas que se estendia por toda parte. Havia uma idade ideal para o casamento - vinte anos para as mulheres e trinta para os homens. Os nascimentos eram rigorosamente controlados, a fim de manter estável o número de habitantes ${ }^{14}$. $\mathrm{E}$ a fim de que cada indivíduo chegasse à mesma alta perfeição da cidade, era exercido um rigoroso controle eugênico, estabelecendo-se o número ideal de casamentos.

Mas o que falta à república platônica, como um dos fundamentos de ligação entre os homens, será encontrado em Epicuro, isto é, a doutrina do hedonismo. A moral epicurista está fundada na idéia de que o fim último da vida humana é a felicidade, e que esta só pode ser encontrada no prazer. A razão deve velar para que o

12 O que na tradição bíblica será relacionado ao "grande dilúvio", e a Atlântida a um dos possíveis lugares onde ficaria localizado o paraíso edênico.

13 PLATÃO. Diálogos - vol. XI. Belém: Universidade Federal do Pará, 1975.

14 Em A República, Platão admitia até mesmo o infanticídio. 
prazer seja puro, isto é, não esteja misturado a nenhuma dor. A fim de evitar a insatisfação é necessário limitar os desejos unicamente aos que são "naturais" como, por exemplo, a fome e a sede. Sua frase mais famosa diz "A fonte e a raiz de todo o bem é o prazer do ventre". Epicuro postula uma espécie de harmonia preestabelecida entre as necessidades e os recursos, entre a natureza individual e a natureza universal, de modo que a pobreza não nasce da raridade dos bens, mas da necessidade não-natural, isto é, do supérfluo ${ }^{15}$.

Mas a apologia da harmonia natural em Epicuro está ligada a uma crítica da sociedade, que aparece, pois, como um artificio. Os homens não estão naturalmente destinados a viver em sociedade. A necessidade que nos torna dependentes uns dos outros é uma prova de fraqueza. Obrigado a viver em sociedade, o homem lança mão de vários meios a fim de se preservar. Um desses meios é a justiça, compreendida não como a realização de uma ordem ideal, como em Platão, mas como uma convenção utilitária, feita em vista de não se prejudicar mutuamente.

Durante a Idade Média, um dos seguidores importantes da filosofia platônica, e que vai retomar o seu sentido de justiça e de ordem, é Santo Agostinho (354-430). A sua cidade ideal é a “cidade de Deus", pensada a partir também do modelo da "comunidade cristã primitiva" ". Já para Thomas de Kempis (1380-1471), Jesus é que é o modelo de vida a imitar, exemplo de simplicidade, desapego das riquezas materiais e justiça bem ordenada ${ }^{17}$.

15 Cf. ABENQUE, Pierre. As filosofias helenísticas: estoicismo, epicurismo, ceticismo. In: CHÂTELET, François (org.). A filosofia pagã. Rio de Janeiro: Zahar, 1983, p. 182-190.

16 SANTO AGOSTINHO. A cidade de Deus. Lisboa: Fundação Calouste Gulbenkian, 2000.

17 KEMPIS, Thomas de. A imitação de Cristo. Lisboa: Europa-América, 1998. 
Neste tempo, havia a forte convicção de que a cristandade deveria integrar, se não um Estado, ao menos uma forte unidade, sob o domínio do Papa e do imperador. Havia uma tendência a ver essa idéia expressa claramente no "Reino Universal" parusíaco do profeta Daniel. Apelava-se para a obra A cidade de Deus, embora Agostinho tivesse dado preferência a uma Igreja e a um modelo de redenção não ligados a determinada concepção de império, mas espalhada em uma infinidade de Estados menores, tal como o queria Platão, o que seria mais vantajoso para a paz universal.

Mas o ideal de pacifismo e o de um império mundial eram absolutamente antagônicos, por pelo menos uma questão, com a qual parecia concordar até mesmo Agostinho. O projeto de formar uma única e grande família cristã em todo o globo - o projeto do Orbis christianus -, como condição de realização da paz e da harmonia entre os homens, esbarra com o obstáculo do paganismo. Por isso, muitos serão os críticos de uma tal empresa. Mas muitos serão também os simpatizantes. E entre os continuadores do sonho do império universal está Dante Alighieri (1265-1321).

E até mesmo Agostinho acaba por se render à idéia, ao postular que o universo inteiro é a imagem da ordem admirável em que o mundo material é regido por forças espirituais, isto é, o Papa (o equivalente do rei-filósofo de Platão). E este sonho não cessaria, persistindo século XVI adentro, mesmo e apesar de uma cristandade dividida pela Reforma.

Um desses continuadores famosos foi sem dúvida Nicolau de Cusa, em sua obra Concordatia catholica (1433). Ele preconiza aí a reconciliação das diversas tendências que sacodem a Igreja, em nome da unidade da fé cristã. Naquilo em que ficou conhecido como sua "filosofia da unidade" ele busca analisar como a unidade infinita se espalha em tudo, originando uma espécie de "otimismo unitário" que muito influenciaria a literatura utópica posterior. Foi 
também quem primeiro rompeu com a tradição aristotélica do mundo fechado sobre si mesmo e defendeu a causa do mundo infinito. Tudo se torna possível a partir de então ${ }^{18}$.

Esta dimensão do "tudo é possível" dá novo ânimo ao imaginário utópico que se vinha formando. A literatura de viagem na era dos descobrimentos desenvolve em larga medida o gosto do maravilhoso e do mistério, impulsiona as idéias mágicas e as fantasias típicas do homem renascentista. Colombo (1451-1506) é o viajante que descobre mas, ao mesmo, tempo conta uma história fantástica. Segue-se uma verdadeira caça às terras incógnitas. Neste tempo havia uma firme crença na proximidade do paraíso terreal.

Discutia-se, inclusive, a possibilidade de o Novo Mundo ser a Atlântida redescoberta. E o narrador-viajante genovês, à vista da ilha do Haiti, tem a certeza de nele haver chegado ${ }^{19}$.

Além da crença bíblica no paraíso terrestre, Colombo tem outra idéia fixa, ligar o mundo através da cruz, isto é, concretizar o ideal do Orbis christianus medieval. Para tanto, dois pontos de partida parecem essenciais. Em primeiro lugar, o mapa de Toscanelli, que não só reforça a sua idéia de que o mundo era redondo, mas também que o Oriente esperava a unidade com o Ocidente ${ }^{20}$. Em segundo lugar, os relatos de Marco Pólo, segundo os quais o imperador da Tartária, conhecido como o Grande Cã, pedia que lhe

18 VEDRINE, Hélène. A nova imagem do mundo: de Nicolau de Cusa a Giordano Bruno. In: CHÂTELET, François (org.). A filosofia do mundo novo. Rio de Janeiro: Zahar, 1983.

19 COLOMBO, Cristóvão. Diários da descoberta da América. Porto Alegre: L\&PM, 1991, p. 64.

20 Os utópicos do século XIX desenvolverão este tema a partir da metáfora da junção da Madre (o Oriente, representando o sentimento) com o Padre (o Ocidente, a razão) 
fossem enviados cem teólogos para que assim se iniciasse a conversão dos mongóis.

Mas se ligar o mundo é a grande empresa de Colombo, é só em uma ilha que é possível descobrir (ou inventar) o paraíso terrestre. Até a segunda viagem ele só havia encontrado ilhas, onde justamente são feitos os mais empolgantes relatos. Em sua carta aos reis católicos, referente à sua terceira viagem, onde ele afirma ter a Terra o formato de uma pêra, fica clara a sua idéia de que o paraíso ficava mesmo localizado em uma ilha ${ }^{21}$. Isto parece confirmar a visão do paraíso associado à Atlântida de Platão.

Esta imagem seria retomada por Desidério Erasmo (14671536). O seu livro mais importante, Elogio da loucura (1508), inicia com uma carta "ao amigo Thomas More". Ele começa com a idéia de "jogar" com o nome de More, "que tanto se aproxima do nome grego da loucura (Moria)", deixando-lhe a seguir a incumbência de defendê-la ${ }^{22}$. Fala então a loucura: "Nasci nas ilhas Afortunadas onde as colheitas não exigem sementeira ou esforço" e onde "o trabalho, a velhice e a doença são desconhecidas". As "ilhas Afortunadas" nada mais são do que a Atlântida perdida, para onde todos os olhos se parecem voltar.

Mas o livro é também uma crítica à "razão louca" ou à loucura que se traveste de razão, isto é, o "mundo fechado" dos teólogos escolásticos, os donos de toda a verdade sobre a vida. Esta ciência, a dos doutores da Igreja, aparecia então como um sonho, uma ilusão, tal como em Platão. Assim, Erasmo defende, em contrapartida, a "loucura sã", aquela dos simples e dos justos da "Santa Escritura", que em tudo buscam imitar a Cristo: "A raça simples da idade de

21 COLOMBO, Diários..., p. 189.

22 ERASMO. Elogio da loucura. Lisboa: Europa-América, 1990, p. 10. 
ouro não possuía ciência alguma, apenas o guiava o instinto da natureza".

Os homens mais felizes são, pois, os que conseguem fugir das ciências e ter como guia a simples natureza. Há aqui, portanto, uma profunda descrença quanto à educação e às demais instituições da época para tornar os homens felizes ${ }^{23}$.

Erasmo acreditava que era impossível melhorar a sorte dos povos enquanto os príncipes continuassem em estado de guerra, enquanto o Papa se mostrasse impotente para fundar a paz dos povos cristãos. Mas aqui entra uma importante contradição, pois a paz dos povos cristãos significava necessariamente a guerra aos infiéis, isto é, a defesa do projeto do Orbis christianus.

A moria de More (1477-1535), a sua Utopia (1516), será, pois, esta "loucura sã" de Erasmo. Neste sentido, o fantástico é também um motivo para a sátira. Isto traz ao sentido platônico do modelo e da realização do modelo, um outro contributo importante para o conteúdo da utopia que se vai remodelando. Os utópicos não buscam um retiro fora da realidade, como normalmente se atribui ao sentido de utopia (ou-topos), isto é, "lugar nenhum". Outro sentido possível do termo, e que se confundia no vocabulário da época era, pois, o de eu-topos, isto é, lugar do bem, ou lugar bom demais para ser verdade, mas que é possível. E sua possibilidade deve necessariamente passar pela crítica da utopia em outro de seus sentidos possíveis, isto é, ordem existente ${ }^{24}$.

A narrativa de More desenvolve-se a partir de um diálogo, ao estilo platônico, entre ele próprio, Pedro Giles (seu amigo, natural

23 ERASMO, Elogio..., p. 60-62.

24 MORE, Thomas. Utopia. Lisboa: Europa-América, 1995 
de Antuérpia) e Rafael Hitlodeu, quase todos personagens reais ${ }^{25}$. O seu objetivo é criticar os "vícios" da sociedade inglesa da época de Henrique VIII e definir a "virtude" própria a uma república feliz.

Hitlodeu é o narrador que viajou "como o grande filósofo Platão", tendo acompanhado Américo Vespúcio em três das suas quatro viagens. A comparação não é inocente. Trata-se da postura própria ao narrador-viajante, isto é, para descobrir outro mundo ou para mudar este é preciso viajar como quem deseja conhecer, despido dos preconceitos, tendo, pois, a postura do filósofo. Daí que More e Giles não queiram saber de Hitlodeu a respeito de "monstros famosos", mas das possibilidades de existência de "uma república justa e sabiamente governada".

Nesse sentido, More tenta convencer a Hitlodeu da importância de seus conselhos para o rei, embora desconfiasse dos "preconceitos e crenças firmemente instaladas", isto é, da razão louca de Erasmo, contra a qual acalenta sua "loucura sã": "Se repetisse as teorias que Platão expressa na sua República e que os utopianos põem em prática, embora sejam efetivamente superiores às que nos regem, admito que poderiam parecer estranhas e absurdas"26.

Segue-se uma descrição da ilha da Utopia e do modo de viver dos utopianos que é muito similar àquela de Platão para sua República: comunidade dos bens (mas não das mulheres), uniformidade e regularidade do espaço e dos hábitos, etc. A única diferença é que o trabalho é tido como sumamente importante em seu projeto de valorização do homem em sociedade. Ele deveria

25 Há na bibliografia sobre o tema uma grande discussão sobre a real existência de Rafael Hitlodeu.

26 MORE, Utopia, p. 54. 
estar organizado de tal forma que evitasse que as pessoas permanecessem por muito tempo numa mesma atividade, contrariamente à divisão do trabalho segundo as funções, preconizada pelo filósofo grego. Mas a noção de justiça também estaria fundamentada na noção de hierarquia, já que haveria uma para o povo e outra para uso dos principados. Daí porque More admitisse a existência da escravidão.

Um dos temas centrais do humanismo, que se destacam na obra de More, e que passaria a compor o conteúdo da utopia, é aquele relativo à primazia do homem, que é descrito em termos de possibilidade. A livre determinação do indivíduo ganha precedência sobre uma essência eternamente fixa, rumo à perfeição da comunidade humana na Terra. Ganham relevo temas como o otimismo de perspectiva e o ideal universalista do homem.

$\mathrm{Na}$ ilha de Utopia o desenvolvimento adequado do indivíduo e até mesmo a sua felicidade dependem da sua integração na sociedade.

Um poeta contemporâneo de More, John Donne, expressou de maneira sintética o cerne do problema da utopia moriana ao dizer: "Nenhum homem é uma ilha, completa em si mesma; cada homem faz parte do continente, é uma parte da grande extensão". A ilha é, portanto, uma metáfora para pensar isto que será, depois, a base do liberalismo burguês, isto é, a ficção do indivíduo autosuficiente, nascendo sozinho, em estado de natureza. Mas, é claro, esta questão ainda não estava posta, ao menos com esta amplitude, na época de More. Mas havia a consciência de que o homem é um ser social e todas as coisas são definidas por sua função e atividade dentro da comunidade. Por outro lado, havia a consciência do enorme abismo que separava pobres e ricos. Daí que a ilha seja sempre cotejada por outro modelo toponímico, isto é, o globo, o 
mundo. Portanto, é somente com More que podemos perceber claramente desenhada, pela primeira vez, uma utopia de tipo social.

O outro tema central do humanismo é o culto do belo, também influenciado pela filosofia platônica. More pede a Hitlodeu que the conte tudo o que ele pensasse que lhe daria "prazer conhecer”. Há, portanto, uma importante dimensão estética na literatura do maravilhoso que deve ser salientada.

Este é também o tema desenvolvido por Rabelais (14831565). Embora seja difícil caracterizar o conteúdo de sua literatura como utópico, há elementos inegáveis de utopia. Em Gargantua (1535), a cidade de Théleme, que em grego significa desejo, vontade, nos introduz em um mundo utópico, espaço de fantasia, e descreve uma civilização luxuosa e refinada, onde as artes aplicadas embelezam a vida cotidiana. Mas ela põe ao mesmo tempo a sociedade de pernas para o ar, ao construir um modelo que pensa ser os atípodas da outra. É a livre determinação e o hedonismo que levam os indivíduos à felicidade. Falando dos habitantes deste novo mundo, acrescenta Rabelais: “Toda sua vida está regrada não por leis, status, ou regras mas sim por seu desejo e livre arbítrio. Come-se, trabalha-se, dorme-se quando se deseja" ${ }^{27}$.

Em Le tiers livre (1546), Rabelais continua o esquema de viagens longínquas para países exóticos ou imaginários. O primeiro capítulo narra como Pantagruel (personagem central) transporta uma colônia de utopianos para Dpsódia. A noção que domina o livro é a do bem-querer recíproco, da assistência mútua. Isto explica o lirismo com que o personagem Panurge celebra a idade de ouro, onde cada um dá e recebe conforme a "lei universal da natureza" 28 . Também em Le cinquiéme livre (1548), ele encontraria uma ilha

27 RABELAIS, François. Gargantua. Paris: Flammarion, 1993, p. 232.

28 RABELAIS, François. Le tiers livre. Paris: Gallimard, 1966. 
onde "as árvores e as ervas não perdem jamais as folhas" ${ }^{29}$, tal qual a visão do paraíso descrito por Colombo ao encontrar o Haiti.

O culto ao belo também se equipara ao elogio do instinto em Michel Montaigne (1533-1592). Em seu ensaio Dos canibais (1579), ele critica o discurso corrente sobre a barbárie dos índios, e questiona simultaneamente os costumes dos europeus. A simplicidade natural daqueles, relacionada a uma pretensa condição humana feliz, é contraposta aos artificios culturais da civilização européia, que sufocam a beleza e a riqueza da natureza. O mero exemplo prático dessas tribos sobrepuja todas as descrições "com que a poesia embelezou a idade de ouro". E referindo-se a Platão, acrescenta: "A república que ele imaginou, como a consideraria distante dessa perfeição" ${ }^{30}$.

Mas o relativismo de Montaigne e o elogio do homem em estado de natureza não renuncia ao paradigma humanista de uma unidade do gênero humano. Foi o rompimento da identidade natural, com a vontade de domínio da razão, que confundiu e perturbou a fisionomia das coisas. Mas ele renuncia sem dúvida ao ideal do Orbis christianus. Está-se inaugurando uma nova era da utopia, e este modelo já não parece imperar sem rivais.

29 RABELAIS, François. Le cinquiéme livre. Paris: Éditions du Seuil, 1997, p. 237.

30 MONTAIGNE, Michel. Os ensaios: livro 1. São Paulo: Martins Fontes, 2001, p. 309. 
Giordano Bruno entra na briga pela diversidade, pela relatividade e abre ainda mais o mundo, dilatando a espaços sem fronteiras a utopia. A possibilidade de "descobrir" ou de "inventar" outros mundos ganha o infinito, e extrapola o topônimo da ilha. O principal livro de Bruno, Sobre o infinito, o universo e os mundos (1580), escrito sob a forma de diálogo, estabelece a inconveniência e a "impossibilidade" de "imaginar" o mundo como existindo em "lugar nenhum". Todas as coisas significam lugar. Assim, um outro mundo é possível, no duplo sentido da palavra. Um mundo diferente daquele estabelecido pelos cânones filosóficos do aristotelismo, mas também daquele ordenado pela Igreja e pela aristocracia. Isto revela também as intenções satíricas da obra de Bruno, que ao ser interrogado sobre as suas intenções de pôr o mundo "de cabeça para baixo", responde: "Considera você errado alguém inverter um mundo virado às avessas" ${ }^{1}$.

Outra novidade importante em Bruno é que ele reanima o animismo epicurista, através da crença em um universo infinito, povoado por infinitos corpos dotados de vida própria. Em sendo assim, tudo está em perpétuo movimento, tudo se renova e se recompõe, estando sujeito a um ótimo eficiente. A doutrina segundo a qual "os contrários existem nos contrários" e que "cada coisa é composta de todas as coisas" estabelece as bases para se pensar a harmonia no universo: "Desta diversidade (de mundos) e oposição dependem a organização, a simetria, a compleição, a paz, a concórdia, a composição, a vida" ${ }^{32}$.

Mas Bruno não descarta o deismo. Isto é, tudo vem do bom, tudo é bom, pelo bom e para o bom, o que resume a excelência de

31 BRUNO, Giordano. Sobre o infinito, o universo e os mundos. São Paulo: Abril Cultural, 1973, p. 63 (Col. "Os Pensadores", vol. 12).

32 BRUNO, Sobre..., p. 63. 
Deus. $\mathrm{O}$ arquiteto do universo e a sua bela ordem podem agora ser contemplados não apenas neste mundo, mas em infinitos outros. Isto introduz uma certa contradição com os fundamentos satíricos da obra de Bruno.

De qualquer forma, não se configura na utopia um simples abandono da vida corrupta para se entregar ao devaneio em suas margens, conforme a crítica corrente.

No prólogo do tradutor espanhol da obra de Traiano Boccalini (1556-1613), Notícias do Parnaso (1605), percebe-se esta maneira dissimulada de falar de coisas perigosas, mas também as suas intenções estéticas: "Este autor é um entre tantos outros que têm escrito neste gênero de mesclar o útil dos conselhos políticos com o gostoso e entretido da invenção" 33 . Trata-se aqui claramente de uma utopia de tipo político.

Está-se, portanto, sempre retomando o problema do modelo formulado por Platão. Tommaso Campanela (1568-1639), em sua obra clássica A cidade do sol (1605), tenta responder a duas objeções normalmente levantadas em seu tempo com respeito a esta questão. Em primeiro lugar, a objeção segundo a qual do que nunca existiu, nem existirá, nem se espera que exista, é inútil e vão tratar. Em segundo lugar, a de que tais modelos são mais conformes à natureza do que provado pelos usos e costumes das nações. A isto o utópico italiano responde que a República de Platão não poderia ser posta em prática apenas pela natureza corrupta do homem. Mas ela existe e pode existir no "estado de inocência", isto é, aquele prefigurado pelas comunidades indígenas da América e aquele a que "Cristo nos faz voltar".

33 BOCCALINI, Traiano. Discursos politicos y aviso del Parnaso. Madrid: Maria de Quinoñes, 1634. 
Assim, a verdade do Evangelho estaria de acordo com o estado de natureza. Isto o provaria ainda as antigas comunidades cristãs e o exemplo dos anabatistas ${ }^{34}$.

A partir daqui começa a desenhar-se com mais nitidez a idéia de buscar na ordem natural, tida como o ideal de uma ordem perfeita, o modelo da ordem para a sociedade. Por essa altura Galileu já tinha exposto suas principais teorias e, portanto, qualquer modelo que se formulasse tomando por referência a natureza, acabaria por se confrontar com o problema da nova ciência e da técnica que se iam vagarosamente desenhando.

E é um discípulo de Campanella quem vai trazer esta novidade para o seio da utopia. Trata-se de Francis Bacon e de seu livro Nova Atlântida (1610). O narrador- viajante, navegando por mares desconhecidos, encontra uma ilha, onde habitava um "povo culto", de "alta humanidade" e "cristãos".

Era a Atlântida, império poderoso em cujo centro encontrava-se a "Casa de Salomão"35, instituição científica que tem por objetivo o "alargamento das fronteiras do império humano, para realizar tudo quanto for possível"36. Este é o preciso momento em que as razões do império deixam de ser religiosas e passam a ser científicas. Ao invés do Orbis christianus, busca-se agora o Orbis cientificus, um mundo perfeitamente dominado e unido pelo poder da ciência. Está-se diante, portanto, de uma utopia de tipo cientificista.

Há um tom profético nas descrições do poder científico e tecnológico da "nova Atlântida".

34 CAMPANELLA, Tommaso. A cidade do sol. Lisboa: Guimarães, 1996.

35 Isaac Newton também falará a respeito de uma tal "casa” em sua obra O templo de Salomão.

36 BACON, Francis. Nova Atlântida. Lisboa: Minerva, 1976, p. 60. 
Entre as inovações merecem destaque a "capacidade de transmitir sons das mais diferentes distâncias" e a "capacidade de imitar vôos de aves", bem como de criar "navios e barcos para navegar debaixo da água". E o desejo de pôr a ciência no lugar da religião, chega ao ponto de fazer da ciência uma nova forma de religião:

"Para os nossos rituais e cerimônias dispomos de duas galerias muito compridas e grandes. Numa delas colocamos padrões e amostras de toda a sorte das mais raras e excelentes invenções; na outra, as estátuas de todos os principais inventores. Temos lá a estátua do vosso Colombo, que descobriu as Índias Ocidentais." 37

Tido por alguns como um texto de antecipação ou mesmo de divulgação científica, a História cômica, de Cyrano de Bergerac (1620-1655), marca um momento importante nesta transformação do conteúdo da utopia ${ }^{38}$. O cômico francês fazia parte do grupo dos chamados "libertinos eruditos", tendo sido aluno, juntamente com Moliére, do epicurista e sensualista Pierre Gassendi (1592-1655), considerado por seus contemporâneos como um dos maiores sábios de seu tempo.

A obra compõe-se de duas partes, uma que narra uma fantástica viagem à lua, outra ao sol. A crença na existência de outros mundos ainda era algo burlesco na época de Bergerac, ao mesmo tempo que podia levar para a fogueira, daí que ele compôs a fábula como uma história cômica, que era uma maneira dissimulada de falar destas coisas. Ele desenvolve temas comuns à nova cosmologia científica, sobretudo aqueles relacionados à relatividade dos lugares e dos movimentos.

37 BACON, Nova..., p. 77.

38 BER GERAC, Cyrano. História cômica ou Viagem à lua. Porto: Leiauto, 1989; e Los paraísos posibles: noticias del outro mundo. Bogotá: Altamir, 1996. 
A possibilidade de voar através do espaço em uma máquina é uma fantasia comum à época. Leonardo da Vinci elaborou o que seria o protótipo de um helicóptero, enquanto que François Godwin, em seu livro O homem na lua (1638), projetou um rudimentar artefato que seria elevado por gansos até o céu infinito. Mas Bergerac inspira-se também no bíblico "carro de Elias"39.

Sua cosmologia está muito mais próxima do animismo de Bruno do que da teoria do movimento desenvolvida por Galileu. Assim, para ele, no universo os corpos semelhantes tendem a juntar-se por "simpatia", "por esse princípio desconhecido de amor através do qual experimentamos que cada coisa busca seu semelhante". Este misto de ciência e fantasia, mostra bem a importância da contribuição renascentista para a composição do conteúdo da utopia.

A dimensão do possível, do onírico, o gosto do maravilhoso, a qualidade mágica são traços que persistem. Um exemplo disto é a possibilidade de reencontrar o Éden bíblico. Em sua versão do paraíso, Bergerac mescla a tradição mitológica grega, do Jardim da Hésperedes, que ele cita no final de sua viagem ao sol, e a tradição judaico-cristã, sobretudo Dante e Ariosto (1474-1533), que o localiza na lua. Não obstante esta referência às tradições do "velho mundo", as intenções satíricas são claras. Pondo o mundo pelo avesso, ele descreve a lua como os antípodas da Terra.

Duas outras novidades, relativamente ao conteúdo da utopia, marcam a obra de Bergerac. Em primeiro lugar, o desaparecimento do filósofo enquanto aquele personagem que aconselha o

39 Posteriormente iriam aparecer várias obras que narram experiências similares, cujo grande exemplo é O descobrimento austral por um homem voador (1781), de Rétif de la Bretone (1734-1806), que será seguido por Júlio Verne (1828-1905). 
rei. O narrador-viajante agora aconselha-se apenas a si mesmo, ou no máximo propõe-se como modelo de conduta para os indivíduos. Durante toda sua viagem ao sol, ele é acompanhado pelo "Demônio de Sócrates", personagem platônico que prefigura a voz interior que lhe faz saber o sentido moral da sua ação. Com reis "tão estúpidos" era impossível reformar o mundo. Há inclusive um ensaio de regicídio ${ }^{40}$.

Em segundo lugar, aparece um problema já levantado por Montaigne, que insere uma importante reflexão a respeito da natureza má do homem, ou de sua tendência para fazer o mal. No sol o narrador-viajante é preso e condenado por descobrirem que ele é homem, "uma calamidade" ante a natureza, uma "peste que deve ser excluída de toda sociedade bem ordenada". Só na Terra, isto é, nas sociedades humanas cujo modelo era a Europa de seu tempo, poderia haver a dominação do mais forte sobre o mais fraco, do homem sobre a natureza, do rico sobre o pobre. Até mesmo o império do Orbis cientificus é então questionado, à medida que ele é contrário às "leis da natureza", diante das quais todos os homens são iguais. Isto põe uma séria interrogação para o otimismo humanista que se vinha desenvolvendo.

Esta tendência de crítica aos valores de civilização, não obstante o relativo entusiasmo pela ciência, ganha um poderoso aliado em Fénélon (1651-1715), em sua obra Aventuras de Telêmaco (1702). Telêmaco, filho de Ulisses, que é o narrador da história, após viajar de ilha em ilha, encontra Betica. "Naquele país ainda parece se conservam as delícias da idade de ouro".Admira-se com

40 Veremos que à medida que a idéia de monarquia for perdendo força na Europa, mais este modelo tende a ser raro. Na era das "Luzes" falar-se-á em reformas feitas pela sociedade civil, enquanto que no século XIX será o sábio, imbuído da ciência, quem deverá cumprir esta missão. 
a vida "simples" e "feliz" que os habitantes levavam. A base da concórdia entre homens era a "inocência dos costumes" e a "boa fé" de cada um. Para além disso, não havia motivos para a concorrência, uma vez que a natureza tudo ofertava, e em abundância. Ao elogio do estado de natureza, corresponde uma corrosiva crítica à civilização, que amolece, afemina, torna as pessoas feias, estimula o luxo, o supérfluo e alimenta a ociosidade ${ }^{41}$.

Este mesmo jogo entre vícios e virtudes, de uma civilização que se mostra cada vez mais bárbara e de um imaginário estado de natureza que seria o ideal de convívio entre os homens, vai-se encontrar em Denis Diderot (1713-1784), Supplément au Voyage de Bougainville (1748). O livro é inspirado no relato de Louis Antoine de Bougainville (1729-1811), navegador francês que deu a volta ao mundo. Quando chega ao Taiti, assim como Colombo quando chegou ao Haiti, maravilha-se pensando ter chegado ao próprio paraíso. O relato, Voyage autour du monde, ressalta, sobretudo, o ideal comunitário que reinava entre os índios.

Tal como More que se viu maravilhado com os relatos de Colombo e Vespúcio, iniciando logo a seguir sua Utopia, Diderot não conseguiu conter seu entusiasmo. A história narra o diálogo entre dois personagens, "A" e "B", a respeito do referido relato de viagem. Voltam alguns dos temas já presentes em Fénélon, mas aqui eles são mais explícitos. A civilização européia aparece como uma "máquina complicada e corrupta", em contraposição à "juventude", ao "frescor", à vida "simples", "feliz" e "livre" dos "selvagens". A palavra liberdade aqui aparece como anátema de propriedade e servidão em um duplo sentido: em relação aos bens

41 Estas idéias estão na raiz do romantismo utópico que se desenvolverá posteriormente, e que vê no progresso capitalista um fator de destruição do meio e do homem. 
e às mulheres. Na comunidade dos taitianos ninguém é proprietário de nada nem de ninguém ${ }^{42}$.

A inocência dos selvagens aparece como a ignorância que é sabedoria, o saber viver, em contraposição às "luzes inúteis", que são ignorância e loucura. Eles medem-se apenas pelo que é necessário e bom para a comunidade, por suas "necessidades naturais", nunca pelo interesse individual. Também sua "beleza", sua saúde, força, destreza e coragem são reflexos desta sabedoria, que é conforme as "leis da natureza" e a base das "leis civis" entre eles. Portanto, os taitianos são um povo de "bons costumes" e "altamente civilizado", ao contrário dos europeus.

Ao fim do diálogo "A" pergunta a "B": "Que fazer então? Retornar à natureza?”. E "B" responde: "Há que falar contra as leis insensatas até que haja reforma". Se é impossível negar o estatuto de civilizado e retornar ao simples estado de natureza, é possível construir uma civilização melhor, desde que se tome como modelo as "leis da natureza". Este ponto marca também o início do reformismo ilustrado como um ideal entre os utópicos ${ }^{43}$.

Mas a precedência da Humanidade sobre os homens, do globo sobre a ilha, no que se fundamentava o otimismo dos utópicos, parece esbarrar com a possibilidade da barbárie. Com Jean-Jacques Rousseau o tema ganha novos argumentos. Em contraposição à natureza, reino da igualdade e da concórdia, aparece a sociedade, geradora de todas as desigualdades e vícios. No estado de natureza o bem-estar e a conservação individual é minimamente prejudicial à outrem. Isto porque o "homem natural" tem repugnância ao ver morrer ou sofrer o seu semelhante. Isto é, o homem, por

42 DENIS, Denis. Supplément au voyage de Bougainville.Paris: Le Livre de Poche, 1995.

43 DENIS, Supplément..., p. 96. 
natureza, só reconhece no outro a sua própria humanidade. A conservação de cada um importa ao todo a que pertencem. Mas como os homens atingiram aquele ponto em que os obstáculos que prejudicam a sua conservação no estado de natureza levam a melhor sobre as forças individuais para se manter neste estado, o único meio de se conservarem passa a ser a associação, isto é, a alienação de cada indivíduo a toda a comunidade ${ }^{44}$.

Em Rousseau é impossível deduzir a ordem social a partir da ordem natural, por mais doloroso que isso lhe seja, pois esta é a própria negação daquela. Fica o eterno sentimento de perda, a nostalgia e uma turva esperança quanto ao futuro.

O mesmo não acontece em Morelly, em seu Código da natureza (1755). Esta é a primeira obra em que o conteúdo da utopia encontrado na literatura precedente ganha o estatuto de um sistema de pensamento, que será depois a base da doutrina do chamado socialismo utópico. Mas o livro parte de um romance, A Basilíade, onde o autor desenha uma sociedade baseada na doutrina comunista. O subtítulo é em si muito significativo "o naufrágio das ilhas flutuantes", isto é, a imersão da ilha no continente, a vitória definitiva do globo. De fato, doravante raros serão os romances utópicos que farão menção à alegoria da ilha ${ }^{45}$.

O livro está organizado segundo cinco teses fundamentais. A primeira delas retoma Rousseau: o homem não nasce nem bom nem mau. Não há valores inatos. São as instituições que corrompem ou educam o homem para o bem. Isto é, não existe mal físico no mundo, o mal é apenas moral. O homem só nasce com suas

44 ROUSSEAU, Jean-Jacques. Discurso sobre a origem e fundamentos da desigualdade entre os homens. Lisboa: Europa-América, 1995; e O contrato social. Lisboa: Europa-América, 1999.

45 MORELLY. Código da natureza. São Paulo: Unicamp, 1994. 
necessidades e seu amor-próprio, seu desejo de conservar-se. Mas a natureza distribuiu as forças aos homens em diferentes proporções, de modo que eles necessitem de se associar para superar a fraqueza das partes. Portanto, a associação não é um artifício da sociedade, como em Rousseau.

Segunda tese: "O mundo é uma mesa guarnecida o suficiente para todos os convivas" 46 . Portanto, a primeira instituição que corrompeu o estado harmônico com que a natureza predispôs a sociedade dos homens foi a propriedade, argumento ao qual Rousseau também não chega. Os dois meios capazes de corrigir este estado vicioso é pondo fim às duas instituições geradoras dele: a propriedade e a educação fundada sobre as ruínas das "leis da natureza". Mas aqui entra uma contradição que é comum a Rousseau, isto é, o estado de natureza pode e deve ser melhorado pela civilização, tornando os "selvagens" "menos grosseiros" e "mais industriosos" como, por exemplo, através do ensino do cultivo da terra e da criação do gado.

A terceira tese estabelece que todo contrato, por sua artificialidade, apenas dá origem a uma sociedade, mas não a um todo unido e coeso. Ele é no fundo uma corrupção do "estado primitivo dos povos", onde predominava a reunião de "famílias associadas", e onde os indivíduos obedeciam apenas "às leis de um sentimento de afeto e ternura suscitado e fomentado pelo exemplo do chefe entre seus irmãos e próximos, doce autoridade que torna todos os bens comuns entre eles" ${ }^{47}$. Foi o fim do "império paternal" e dos "laços de consangüinidade" que originou toda a desordem e a ruína de toda forma de sociabilidade.

46 MORElly, Código..., p. 28.
47 MORElly, Código..., p. 50. 
A quarta tese postula e busca responder a seguinte questão: como ordenar, de acordo com as leis da natureza, as desigualdades naturais dos homens, de modo a formar um todo harmonioso e coeso? "Direi que tudo isso seria uma simples questão de enumeração de coisas e pessoas, uma simples operação de cálculo e combinação, e, portanto, passível de uma belíssima ordem". E sobre que base seria feita esta combinatória? A partir de uma operação de coordenação das diferentes funções sociais, de acordo com as forças próprias com que a natureza dotou cada indivíduo. A associação, a ligação potencia a ação de cada membro individual da sociedade, assim como o organismo humano funcionando em uníssono potencia a ação de cada órgão. Esta é a primeira vez que, entre os utópicos, aparece uma comparação desta natureza, entre o social e o biológico, a partir de uma suposta ordem natural ${ }^{48}$.

A quinta tese introduz um certo sentido da hierarquia que vinha sendo perseguido pelos utópicos desde More: "O todo vale mais do que a parte, mesmo a melhor; a humanidade inteira vale mais do que o melhor dos homens, e uma nação é preferível à mais respeitável família e esta ao mais respeitado dos cidadãos" ${ }^{49}$. Isto reflete-se na obsessão de Morelly pela regularidade, pela organização, pela uniformidade, pela ordenação, seja do espaço, seja da vida das pessoas, o modo de se vestir, de produzir, de distribuir, a idade ideal para casar, quantos filhos ter, etc. Enfim, nenhum esforço é poupado a fim de apagar da sociedade todas as marcas do individualismo, sinônimo de corrupção.

Mas Morelly só vê o mal fisico no mundo civilizado, uma decorrência quase mecânica do mal moral. O que não é exatamente o otimismo metafisico de Leibniz, segundo o qual o homem vive

\footnotetext{
48 MORELLY, Código..., p.54.

49 MORELLY, Código..., p. 67.
} 
no melhor dos mundos. O mundo civilizado chega a ser mesmo o pior dos mundos.

É contra este otimismo leibniziano que Voltaire (1694-1778) se insurge em seu romance Cândido (1758). Mas a obra é simultaneamente uma crítica ao pessimismo daqueles que viam no homem um ser malvado e infeliz. Portanto ele vai partir das mesmas bases de raciocínio definidas por Rousseau e Morelly, isto é, que o homem não nasce nem bom nem mau. Com a diferença de que ele se recusa a ver na natureza qualquer sinal de bondade. Mal e bem são realidades eminentemente sociais.

Cândido, o herói da narrativa, "dotado pela natureza das melhores qualidades", como a ingenuidade e a pureza, e ao mesmo tempo educado no "mais belo e agradável dos castelos do mundo", recebe suas lições de Pangloss, o "filósofo zarolha", encarnação grotesca do otimismo de Leibniz.

Cândido é bom, confia nos homens e em sua bondade natural. $\mathrm{E}$, às vezes, até encontra pessoas dispostas a ajudar e ser solidárias, como o médico anabatista Tiago e a velha que cuida de suas feridas e dá-lhe abrigo e comida. Mas em suas aventuras (e desventuras) pelo mundo é com o mal físico (catástrofes naturais, como o terremoto de Lisboa) e moral (o ódio, a injustiça, a opressão do homem pelo homem, a rapina; como, por exemplo, as pessoas que se aproveitam do terremoto para roubarem e pilharem as casas) que ele vai esbarrar constantemente.

Cansado de ver tanta maldade e desgraça pela Europa parte para o "Mundo Novo", na esperança de lá encontrar a ordem perfeita. Mas aí sofre sua segunda decepção. É quase comido pelos canibais do Paraguai e está prestes a renunciar a filosofia de seu mestre: "Ah, o que diria Pangloss, se visse como é feita a natureza 
pura dos selvagens!" ${ }^{50}$. Extenuado, Cândido adormece numa jangada e quando acorda depara-se com um lugar maravilhoso, paradisíaco, era o Eldorado, onde finalmente foram recebidos e muito bem tratados pelos habitantes. É, portanto, somente através dos sonhos que é possível encontrar um lugar onde tudo vai bem.

Ao deixar o paraíso pela segunda vez, já que a primeira fora quando expulsaram- no do castelo, conclui que a única coisa boa deste mundo era rever a menina Cunegundes, que prefigura o amor e a esperança. E é somente por ela que ele acredita ser possível continuar em suas desventuras pelo mundo. Ao fim, Pangloss já não acredita nas próprias posições, embora acreditasse fosse preciso mantê- las. Cunegundes, embora já "velha e horrivelmente feia", continua sendo o grande amor de Cândido. E o trabalho comum é a única maneira de mantê-los unidos e confiantes no futuro: "O que sei é que é preciso cultivar o nosso jardim"

O livro de Voltaire não é, pois, uma distopia, mas uma revitalização da idéia do sonho como fator construtivo. Não há ordem nem na natureza nem na sociedade e o melhor dos mundos é uma quimera impossível. Mas um mundo melhor é possível. E ele inclusive pode ser o pior dos mundos, pois não há como prever. Tudo o que há é a esperança e a disposição para trabalhar e torná -lo melhor.

No final do século XVIII tais utopias sociais encontrariam em Gracchus Babeuf (1760-1797) um defensor radical: "Tudo corre o melhor possível, diz-se. Sim, para os aristocratas e os inimigos da liberdade. Uma enorme carestia faz sofrer e morrer de fome o operário pobre". Por esta altura já havia ocorrido a Revolução Francesa, onde muitos depositaram as suas esperanças de um

50 VOLTAIRE. Cândido. Lisboa: Europa-América, 1987, p. 67.

51 VOLTAIRE. Cândido, p. 145. 
mundo mais igual e fraterno. Mas, uma vez mais, a realidade contradisse os sonhos e Babeuf interroga-se, um tanto cético: "Onde está o bem que o novo regime já nos proporcionou?" 52 .

A grande novidade que Babeuf traz para o conteúdo da utopia é o seu igualitarismo radical. Antes criticava-se os excessos da civilização, o consumo supérfluo, o luxo, o desperdício, mas sem identificá-lo a qualquer camada da sociedade. Agora eles são identificados com uma minoria ociosa - a aristocracia, o clero - que goza, enquanto a maioria dos "trabalhadores" e "camponeses” vivem na penúria. Neste sentido, Babeuf não considera nem mesmo as diferenças naturais, já que em ao menos um sentido eles são radicalmente iguais, isto é, na "capacidade de seu estômago". A propriedade só diz respeito ao trabalho que o gera. Portanto, tudo que é produzido pela sociedade é da sociedade como um todo.

Cético quanto ao contrato social, Babeuf recai no argumento da ordem natural como prefiguração da ordem social, um dos principais argumentos dos diferentes tipos de utopia:

"Estou convencido que o estado de comunidade é o único justo, o único bom, o único conforme aos puros sentimentos da natureza, e que, fora dele, não podem existir sociedades pacíficas e verdadeiramente felizes (...) Se é assim que as coisas se passam, não consigo ver por que motivo a possibilidade eventual de um regresso ao estado comunitário há-de ser apenas um sonho." ${ }^{53}$

\section{Conclusão}

5252 BABEUF, Gracchus. O tribuno do povo. Lisboa: Iniciativas Editoriais, 1977, p. 24 e p. 35.

53 BABEUF, O tribuno..., p. 72 e p.75. 
A imagem da utopia como mero sonho, fantasia ou evasão da realidade, não parece mais ser aceita pelos estudiosos do tema. Tampouco ela parece revelar-se exclusivamente através do seu conteúdo revolucionário. Ao longo dos séculos, desde Platão, houve um número muito grande de utopias, correspondentes aos diferentes contextos em que tais literaturas se viram nascer.

Mas o que permite então falar em utopia como um dado conceito, uma realidade ou conteúdo que perpassa todas estas diferentes manifestações literárias? Conforme vimos, a mundividência utópica revela uma série de elementos comuns: o modelo e a realização do modelo; a busca da unidade social e de uma sociedade harmônica e concorde, onde o todo é mais importante que as meras partes constituintes e conflitantes; enfim, a busca de uma ordem perfeita. Cada utópico, em diferentes momentos, elaborou estes conteúdos de forma distinta: Platão, através de uma perfeita hierarquização das funções sociais; Morelly através de uma imitação da ordem natural por parte da ordem social; Babeuf através de uma radicalização do conteúdo igualitário dos princípios da Revolução Francesa, e assim por diante.

Mas o sentido mais importante e atual talvez seja o não conformismo, a não aceitação de nenhuma realidade como definitiva, a não ser aquela que eleve ao mais alto grau as potencialidades humanas, isto é, o otimismo de perspectiva e o ideal universalista do homem. Conforme a mensagem de Cândido, personagem de Voltaire, hoje repetida entre aqueles que ainda acreditam em alguma forma de utopia, "um mundo melhor é possível". 


\section{Bibliografia}

ABENQUE, Pierre. As filosofias helenísticas: estoicismo, epicurismo, ceticismo. In: CHÂTELET, François (org.). A filosofia pagã. Rio de Janeiro: Zahar, 1983, p. 182-190.

BABEUF, Gracchus. O tribuno do povo. Lisboa: Iniciativas Editoriais, 1977. BACON, Francis. Nova Atlântida. Lisboa: Minerva, 1976.

BERGERAC, Cyrano. História cômica ou Viagem à lua. Porto: Leiauto, 1989.

BER GERAC, Cyrano. Los paraísos posibles: noticias del outro mundo. Bogotá: Altamir, 1996. BOCCALINI, Traiano. Discursos politicos y aviso del Parnaso. Madrid: Maria de Quinoñes, 1634. BORNHEIM, Gerd A. (org.). Os filósofos pré-socráticos. São Paulo: Cultrix, 1993.

BRUNO, Giordano. Sobre o infinito, o universo e os mundos. São Paulo: Abril Cultural, 1973. BUBER, Martin. O socialismo utópico. São Paulo: Perspectiva, 1971.

CAMPANELLA, Tommaso. A cidade do sol. Lisboa: Guimarães, 1996.

COLOMBO, Cristóvão. Diários da descoberta da América. Porto Alegre: L\&PM, 1991. DENIS, Denis. Supplément au voyage de Bougainville. Paris: Le Livre de Poche, 1995.

ENGELS, F. Do socialismo utópico ao socialismo científico. In: MARX, K. \& ENGELS, F. Obras escolhidas. São Paulo: Alfa-Omega, s.d. 
ERASMO. Elogio da loucura. Lisboa: Europa-América, 1990.

KEMPIS, Thomas de. A imitação de Cristo. Lisboa: Europa-América, 1998.

LÖWY, Michel. As aventuras de Karl Marx contra o Barão de Münchhausen. São Paulo: BuscaVida, 1987.

MANNHEIM, Karl. Ideologia e utopia. Rio de Janeiro: Guanabara, 1986.

MARX, Karl. Manifesto do Partido Comunista. In: MARX, K. \& ENGELS, F. Obras escolhidas. São Paulo: Alfa-Omega, s.d.

MONTAIGNE, Michel. Os ensaios: livro 1. São Paulo: Martins Fontes, 2001. MORE, Thomas. Utopia. Lisboa: Europa-América, 1995.

MORELLY. Código da natureza. São Paulo: Unicamp, 1994. PLATÃO. A República. Lisboa: Europa-América, 1998.

PLATÃO. Diálogos - vol. XI. Belém: Universidade Federal do Pará, 1975. RABELAIS, François. Gargantua. Paris: Flammarion, 1993.

RABELAIS, François. Le cinquiéme livre. Paris: Éditions du Seuil, 1997. RABELAIS, François. Le tiers livre. Paris: Gallimard, 1966.

ROUSSEAU, Jean-Jacques. Discurso sobre a origem e fundamentos da desigualdade entre os homens. Lisboa: Europa-América, 1995. 
ROUSSEAU, Jean-Jacques. O contrato social. Lisboa: EuropaAmérica, 1999.

SANTO AGOSTINHO. A cidade de Deus. Lisboa: Fundação Calouste Gulbenkian, 2000.

VEDRINE, Hélène. A nova imagem do mundo: de Nicolau de Cusa a Giordano Bruno. In: CHÂTELET, François (org.). A filosofia do mundo novo. Rio de Janeiro: Zahar, 1983.

VOLTAIRE. Cândido. Lisboa: Europa-América, 1987. 